\title{
MEMOIR
}

\section{REGINALD GEORGE MAUDLING}

An event which caused a flutter at the time, but which must now be largely forgotten, brought about a change in the direction of the career of Reginald George Maudling. 'This event was the failure, after two years' existence, of an insurance company-the Omnium Insurance Corporation Ltd.-which had set out, with a flourish of trumpets, to undertake insurance business of all kinds. Prior to his appointment as Actuary and Life Manager of the Omnium in January I910, Maudling had, on leaving the Merchant Taylors' School, entered the service of the London and Lancashire (qualifying in 1909) and subsequently for a short period worked with T. G. Ackland. The early collapse of the Omnium in no way reflected upon his capacity -indeed, the Life Department for which he was responsible had the unique distinction of never having to meet a claim throughout the whole period of the existence of the Company-but one consequence of the failure was the disappearance of his post. He accordingly approached A. W. Watson. It so happened that when Watson heard his name he remembered that Maudling had been the only candidate to answer satisfactorily an examination question on friendly societies which Watson had set, and he immediately offered him a post. The evidence of ability afforded by this fortuitous encounter served to release Maudling from the precarious position into which the failure of the Omnium had plunged him and Watson's offer became the turning point in his career, for soon after this the Government required the services of Watson, following the passing of the National Insurance Act, I9II. This involved his giving up his private consulting practice. By this time Watson had discovered the sterling qualities of his new assistant, and so it came about that Maudling became the senior partner in a firm of Consulting Actuaries which for 40 years had been the only firm of its kind in existence in the United Kingdom.

Maudling possessed all the qualities which are valuable for a Consulting Actuary. In addition to being very competent as an actuary he was a first-class business man, with an exceptionally wide knowledge extending well beyond his purely professional sphere. Moreover, he was an eminently friendly person who was popular wherever he went. He had a rare capacity for work, and by the discipline of his powers was able to achieve an amazing output. With it all he had a great sense of fun and in conference or committee work could be puckishindeed, many such conferences are mainly remembered for the highly amusing comments contributed unexpectedly by Maudling. There were times when his very exuberance and enthusiasm left him unaware of the thoughts of others present, but there was never any unfriendliness in his sudden incursions. Despite his readiness of tongue he never really learned to make a speech. His capacity for clear written expression came as a result of a vigorous disciplining of an active mind, and this made him an outstanding draughtsman with a flair for the exact and persuasive use of words, which he may well have inherited from his father, who was a well-known City solicitor, or acquired from Watson, whom he greatly admired. Many of his reports, read years later, give one the satisfying feeling of setting forth with admirable clarity and balance the essence of the matters with which they dealt. 
Maudling was a great believer in 'extending the scope of the profession', and in many ways he was quick to sense the kind of service which would meet a need in the world of business. It was this faculty which led him to establish a Company which offered expert calculating assistance to businesses which needed such help from time to time. The rapid growth of this enterprise showed clearly his capacity for accurate diagnosis.

Maudling was a member of the Council from I918 to 1923 and from 1929 to 1936, and served the Institute as Vice-President from 1934 to 1936 . He contributed a paper in 1929 on the Classification and Duration of Compensation Claims in the Mining Industry, and one review to the Fournal. He also served on the Departmental Actuarial Committee to advise the Royal Commission on National Health Insurance and on the Joint Sub-Committee of the Nurses and Midwives Salaries Committee, England and Scotland.

As one thinks of Maudling after $4 \mathrm{I}$ years of close contact with him certain outstanding characteristics of his tend to arise immediately in one's thoughts. First, the creative quality of his mind, capable of pouring out a veritable torrent of ideas; this output called at times for critical selection, but he was always open to criticism of a positive kind, and valued such co-operation. Coupled with this were a phenomenal memory and a high sense of principle and moral integrity. He was, in modern jargon, essentially an extrovert, with limited self-knowledge, showing itself sometimes in a certain lovable naiveté. But perhaps he is best remembered for his generous nature and a warm-heartedness which not only endeared him to others but called forth an answering affection.

In his younger days Maudling was a keen cricketer and had a great love for the game. He was also fond of golf, but with the increasing demands of business these earlier loves became crowded out, he found little time for outside interests, and it was fitting that, although past 70 years of age, he died in harness. He had successfully survived an operation, and was apparently making rapid progress towards recovery, when he suddenly collapsed and was gone. It had been hoped that he would still have been spared to serve as Consultant Partner the firm whose fortunes he had guided with such distinction for nearly 42 years.

He leaves a widow and one son, and two grandchildren. Maudling was always reticent-even shy-in referring to those of his own home and family, but to those who knew him more intimately it was clear with what depth of affection he regarded them. He followed with pride, which he was at pains to conceal, his son's progress and distinction at School, at University, in the Air Ministry and as a member of the House of Commons, and it is good to know that he survived to see him, at an early age, appointed Economic Secretary to the Treasury. 